\title{
Occupational Factors Contributing to Low Self-esteem in Registered Nurses and Licensed Practical Nurses: A Multivariate Analysis
}

\author{
Kaori IMAI \\ Department of Public Health Nursing, School of Health Sciences, University of Occupational and \\ Environmental Health, Japan. Yahatanishi-ku, Kitakyushu 807-8555, Japan
}

Abstract: The present study examines job-related factors leading to low self-esteem in nurses. The lowering of self-esteem suggests that such nurses had difficulty in fully accepting themselves and their circumstances. Subjects were registered nurses (RN) and licensed practical nurses (LPN) at hospitals, and unemployed registered nurses (UEN) seeking employment. Questionnaires were provided at 53 hospitals and a Nurse Bank in Kanagawa Prefecture. The responses of 552 RN, 146 LPN and 433 UEN were analyzed. Questions were asked about personal life, past or present nursing experience, working conditions, nursing skills, satisfaction with work performance and self-esteem. Factors giving rise to low self-esteem were determined using logistic regression analysis and logistic discriminant analysis. Employment status and qualifications were determined to be the most important factors determining the self-esteem of nurses. The next most important factors were 'a limited number of years of experience (less than five years)' and 'dissatisfaction with discretion and responsibility as a nurse' $(P<0.01)$. Adjusted odds ratio for a reduction in self-esteem for LPN was 4.07 times higher than for UEN, and 2.2 times higher than for RN by logistic regression analysis. LPN are treated as unskilled workers, and thus significant differences were apparent in their performance of certain job tasks. These differences were analyzed using discriminant analysis, and were referred to as follows, 1 : Advanced assessment skills, 2 : Advanced technical skills, 3 : Advanced communication skills, and 4 : Nursing plan and documentation (positive discrimination rate was $70.8 \%$ ). Job dissatisfaction is closely associated with the level of professional training. Continuous education and a feedback system for various levels of nurses are needed.

Key words:self-esteem, registered nurse, licensed practical nurse, logistic discriminant analysis.

(Received 15 August 2000, accepted 30 January 2001)

\section{Introduction}

Nurses have a comparatively short career relative to other professions traditionally occupied by women, and although hospitals need a wide age range of nurses, many nurses leave 
their jobs while still young $[1,2]$. This situation has arisen from the working conditions and problems encountered by nurses in the performance of their duties. The present study examines problems involving work-related dissatisfaction, self-esteem and present job description (nursing skills) among registered nurses and licensed practical nurses in hospitals, as well as among unemployed nurses. We attempted to clarify the factors underlying loss of self-esteem in nurses. Self-esteem $[3,4]$ manifests as a positive attitude towards oneself. The lowering of self-esteem suggests that the nurses have difficulty in fully accepting themselves and their circumstances. This potentially leads to the onset of burnout syndrome and early resignation $[5,6]$.

\section{Study Methods}

\section{Subjects}

Subjects were nurses working at hospitals as registered nurses (RN) and licensed practical nurses (LPN), and unemployed registered nurses (UEN) who had left their jobs and were seeking employment at a nurse bank. Questionnaires were sent directly to a nurse bank, and were forwarded to nurses who visited there. For employed nurses (RN and LPN), questionnaires were sent to 53 hospitals selected at random by a systematic sampling method according to size from the hospital directory of Kanagawa Prefecture according to a hospital list.

Questionnaires were distributed to 1,225 employed nurses, with $696 \mathrm{RN}$ and $185 \mathrm{LPN}$ responding. Questionnaires containing responses with no answer variables selected were excluded from analysis; the remaining respondents, consisting of $552 \mathrm{RN}$ and $146 \mathrm{LPN}$ were analyzed (effective response rate was $57.0 \%$ ). Of 800 UEN who were sent a questionnaire, 433 responded, and 352 were analyzed (effective response rates were 54.1 and $44.0 \%$, respectively).

\section{Questionnaire}

Questionnaires sent to RN and LPN at hospitals consisted of the following: (1) personal profile, (2) self-esteem by the Rosenberg method [3], 10 items in 4 scales. (3) Present working conditions (division, night duty, working hours) and job dissatisfaction: 12 questions in 4 scales of satisfaction. (4) Present job description: experience and 4 graded frequency regarding each of 64 nursing skills specified by the clinical nursing performance examination [7]. Questionnaires sent to UEN consisted of (1), (2), (3) past working conditions at most recent hospital and job dissatisfaction, and (4) job description at most recent hospital.

\section{Analysis}

Self-esteem by Rosenberg is presented as total score of 10 questions, distributed 0 to 40 . Mean and standard deviation (SD) of the scores were 24.2 and 5.4, respectively. In order to examine factors affecting self-esteem, respondents were classified into the following three 
groups referenced by 1 SD: low self-esteem (less than 20 score, $20.1 \%$, moderate self-esteem

(21-29 score, 60.0\%), and high self-esteem (more than 30 score, 19.9\%).

Regarding job dissatisfaction of 4 scales, the dissatisfied group included scale 1 (feel keen dissatisfaction) and 2 (rather dissatisfied).

Logistic regression analysis was applied using the low self-esteem group and high selfesteem group as the objective variables. Analyses were carried out using the following variables as explanatory variables: marital status, number of children, nursing department, working years, experience and frequency regarding nursing skills, and level of dissatisfaction. For calculation, PC-SAS Ver. 6.11 was used.

As the most effective variable to explain self-esteem, differences in the job description between RN and LPN were analyzed. For each of the 64 nursing skills, a performing group and a non-performing group were determined. The performing group consisted of nurses who performed each skill frequently (i.e., performed sometimes to everyday). The remaining nurses comprised the non-performing group.

A comparison of the percentage of nurses in the performing group between RN and LPN was made for each nursing skill. Furthermore, to clarify the differences in job description, a discriminant analysis was conducted. For the analysis, the logistic method using the maximum likelihood method was applied. The combination of nursing skills that most clearly explained the difference between RN and LPN was analyzed. The RNs were randomly divided into 4 groups, each with 115 nurses ( $R N 1$ to RN 4 group), which were almost balanced with the LPN group with 103 nurses. At first, LPN and one of RN (RN 1) group were used to determine the equation for discrimination that classified RN and LPN. Next, based on the equation from RN 1 and LPN, the validity (robustness of the equation) was tested for applying the criteria against the remaining three RN groups (RN 2 to RN 4). LPN could not be divided because the number would have become insufficient for the analysis if divided.

\section{Results}

\section{Subject characteristics}

The age distribution is shown in Fig. 1. A total of $64 \%$ of RN and $40 \%$ of LPN were in their twenties, while $58.2 \%$ of UEN were in their thirties. Most RN had less than 3 years of work experience, while LPN constituted most of those with more than 10 years. Most UEN had 5 to 10 years of experience. In terms of marital status, the percentage of married nurses was $56.4 \%$. This percentage in the RN, LPN, and UEN groups were 35, 47, and 94 $\%$, respectively. Also, $50.2 \%$ of the total group had children, and this value in each individual group was $28.3,47.3$ and $85.3 \%$, respectively.

In terms of place of work, the largest percentage of the RN and LPN, at more than $40 \%$, worked in the department of internal medicine, followed by surgery, pediatrics, maternity, psychiatric department, intensive care unit (ICU) and operation room as an attendant. 


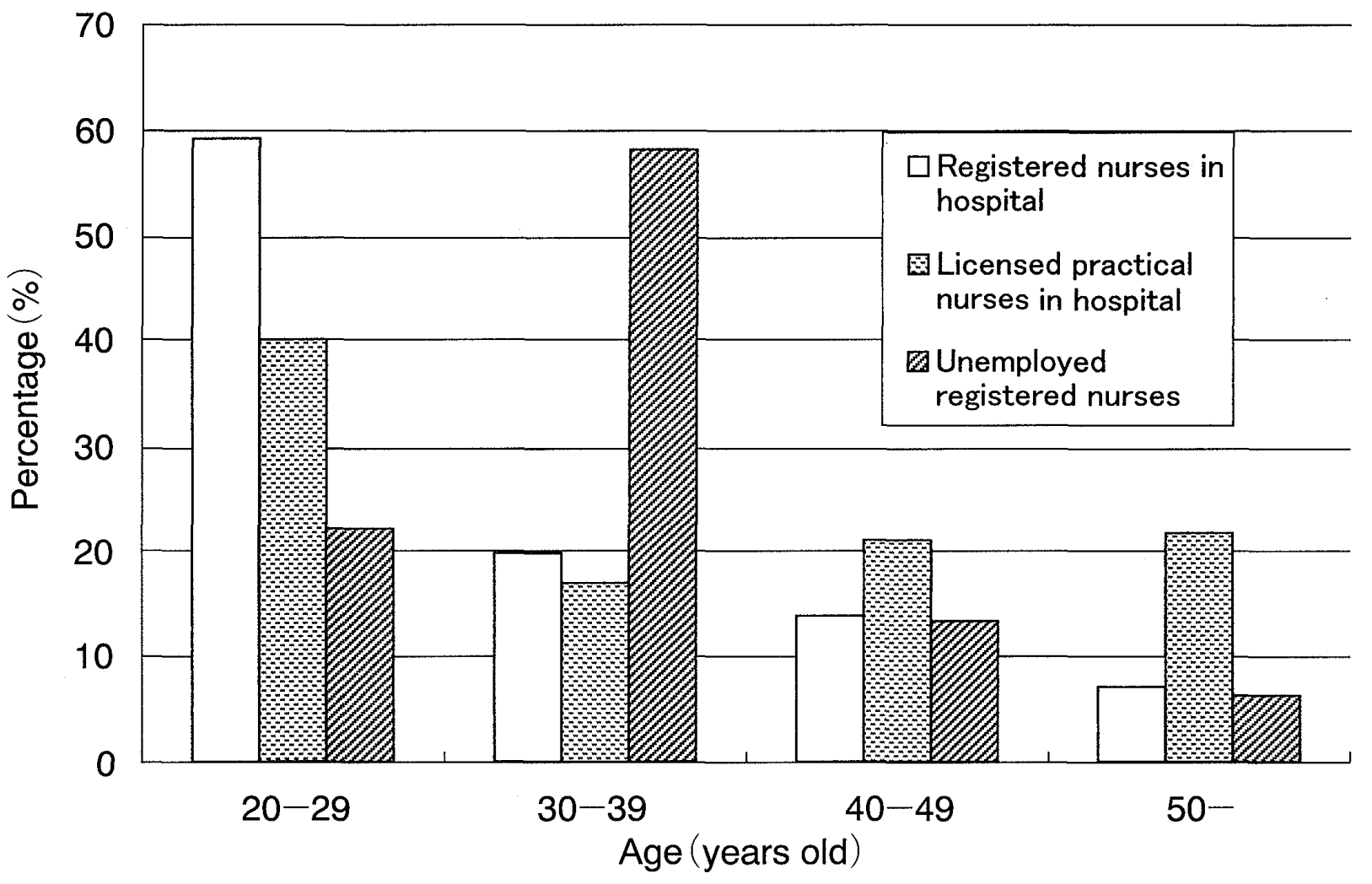

Fig. 1. Age distribution of nurses by current status and qualification.

\section{Job related dissatisfaction}

Table 1 shows that dissatisfaction is due mostly to salary and self-evaluation of social standing, followed by workload. LPN reveal greater dissatisfaction than RN in terms of their opportunity to receive education and the number of nurses working night shifts.

\section{Items that enhance low self-esteem}

The most important variables for determining self-esteem were employment status and qualifications. Self esteem of UEN was higher than employed RN and LPN. The percentage of LPN with low self-esteem was $30 \%$, and this value was significantly higher than that of RN $(23.9 \%)$ and UEN (11.6\%). The other significantly important variables were years of experience, dissatisfaction with discretion and responsibility as a nurse, marital status and number of children $(P<0.05)$. Having a family did not decrease self-esteem, but contributed to positive self-esteem. Nurses with more than two children had high self-esteem. Regarding years of experience, an association between limited experience and low selfesteem was observed among nurses, especially in RN.

Table 2 shows the most effective combination of variables that explained low self-esteem, 
Table 1. Proportion of nurses who expressed dissatisfaction with working conditions

\begin{tabular}{llll}
\hline \multicolumn{1}{c}{ Content of dissatisfaction } & RN & LPN & UEN \\
\hline Relation with colleagues & $17.2 \%$ & $23.8 \%$ & $20.5 \%$ \\
Relation with superior officials & 29.2 & 36.7 & 38.9 \\
Relation with doctors & 46.0 & 49.7 & 36.9 \\
Education and training & 48.7 & 60.5 & 46.6 \\
Discretion and responsibility & 32.1 & 46.3 & 32.1 \\
Opportunity to demonstrate ability & 36.4 & 46.3 & 36.6 \\
Frequency of night shift duty & 39.9 & 46.3 & 50.0 \\
Number of nurses on night shift & 48.7 & 61.9 & 53.4 \\
Workload & 66.7 & 73.5 & 69.3 \\
Chance for promotion & 38.8 & 42.9 & 55.7 \\
Salary & 74.6 & 78.2 & 74.4 \\
Self-evaluation of social standing & 76.8 & 77.6 & 71.6 \\
\hline
\end{tabular}

RN: Registered nurses in hospital, LPN: Licensed practical nurses in hospital UEN: Unemployed registered nurses

Percentage includes 'dissatisfied' and 'rather dissatisfied' .

Table 2. Selected variables which were independent of one another and associated with self-esteem of nurses

\begin{tabular}{|c|c|c|c|c|c|}
\hline Item & Coefficient & $\begin{array}{l}\text { Standard } \\
\text { error }\end{array}$ & Probability & Category & Odds ratio \\
\hline Intercept: & 2.48 & 0.476 & & & \\
\hline \multirow{3}{*}{$\begin{array}{l}\text { Employment status and } \\
\text { qualification }\end{array}$} & & & & UEN & 1 \\
\hline & 1.058 & 0.310 & 0.0006 & $\mathrm{RN}$ & 2.2 \\
\hline & & & & LPN & 4.07 \\
\hline \multirow[t]{2}{*}{ Years of experience } & 0.712 & 0.173 & 0.0001 & $<5$ years & 2.88 \\
\hline & & & & $>5$ years & 1 \\
\hline \multirow{2}{*}{$\begin{array}{l}\text { Dissatisfaction with } \\
\text { discretion and responsibility }\end{array}$} & 0.918 & 0.323 & 0.0045 & $(+)$ & 2.5 \\
\hline & & & & $(-)$ & 1 \\
\hline
\end{tabular}

RN: Registered nurses in hospital, LPN: Licensed practical nurses in hospital

UEN: Unemployed registered nurses

Significance determined by logistic regression analysis.

Objective variable included high self-esteem group and low self-esteem group.

and which were independent of one another according to logistic regression analysis. Selected variables were 'years of nursing experience', 'employment status and qualifications' and 'dissatisfaction with discretion and responsibility as a nurse'. The odds ratio for 'less 
Table 3. Selected skills expressed differences in job description between registered nurses and licensed practical nurses in hospital using logistic discriminant analysis

\begin{tabular}{|c|c|c|}
\hline Nursing skills & \multicolumn{2}{|c|}{ Proportion of performed group } \\
\hline 1: Advanced assessment skills & $\mathrm{RN}$ & LPN \\
\hline Assessment of patient consciousness & $87.5 \%$ & $72.6 \%$ \\
\hline Evacuation of cardiac monitor strip & 81.9 & 70.6 \\
\hline Auscultatation of breath sounds & 90.4 & 76.0 \\
\hline Auscultatation of bowel sounds & 88.2 & 76.7 \\
\hline \multicolumn{3}{|l|}{$2:$ Advanced clinical skills } \\
\hline Maintaining endotracheal tube in secure position & 78.3 & 65.8 \\
\hline Providing passive ROM to immobilized patients & 74.5 & 63.7 \\
\hline Confirm effectiveness of medication prior to administering & 82.8 & 68.5 \\
\hline Checks central venous pressure & 57.6 & 42.5 \\
\hline Take appropriate action when alarms (patient-ventilator system) sound & 71.0 & 52.3 \\
\hline Checks patient SMA results $\left(\mathrm{K}^{+}\right.$, glucose $)$ & 86.2 & 69.9 \\
\hline \multicolumn{3}{|l|}{ 3: Advanced communication skills } \\
\hline Provide means of communication for intubated patient & 67.8 & 47.3 \\
\hline Family support and other significant roles & 90.2 & 75.3 \\
\hline \multicolumn{3}{|l|}{4 : Nursing plan and documentation } \\
\hline Document patient instruction & 78.3 & 57.5 \\
\hline Nursing plan preparation & 81.5 & 62.3 \\
\hline
\end{tabular}

RN: Registered nurses in hospital, LPN: Licensed practical nurses in hospital

Presented skills were selected from among 64 questions specified by the clinical performance examination [7].

than five years of experience' was $2.88(P<0.01)$ against 'more than five years'. The odds ratios were 2.2 $(P<0.01)$ for $\mathrm{RN}$ and $4.07(P<0.01)$ for $\mathrm{LPN}$, against $\mathrm{UEN}$.

\section{Differences in job description between $R N$ and $L P N$}

Skills that show significant differences in the level of experience between RN and LPN were selected from among 64 questions. A total of 25 items showed a significant difference $(P<0.01)$ in proportion to the performing group and non-performing group between $\mathrm{RN}$ and LPN. Among the above 25 skills, the combination of skills that most clearly explained the difference was determined using discriminant analysis. These skills were 1: Advanced assessment skills, 2 : Advanced clinical skills, 3 : Advanced communication skills and 4 : Nursing plan and documentation (Table 3 ). A positive discrimination rate of $70.8 \%$ was found in the LPN and RN 1 groups. To confirm the accuracy of the criterion, the obtained equation was applied also to the LPN and other RN groups ( RN 2-RN 4). The obtained rate was 66.5 to $69.1 \%$, which is within the acceptable range. 


\section{Discussion}

Employment status and qualifications were determined to be the most important factors for determining the self-esteem of nurses. Employed nurses, especially LPN revealed lower self-esteem than UEN. A secondary factor associated with low self-esteem was a limited number of years of experience. Munakata [8] reported that nurses and teachers with a limited number of years of experience expressed low self-esteem. As a common factor for both jobs, there is an insufficient level of occupational training and support systems.

In terms of their family, results suggested that the family demands did not interfere with job satisfaction. Kandolin [9] also reported that family role did not correlate with burnout on the part of nurses. Compared with UEN, the odds ratio of employed RN was 2.2, suggesting that the nurses experienced job-related stress. Many nurses expressed dissatisfaction with their self-evaluated social standing, as well as with their salary and workload. Also, in western countries, a shortage of nurses due to early resignation as a result of job related stress has been reported $[10,11]$. Fimian $[11]$ noted that due to stress related factors, $60 \%$ of nurses expressed a desire to leave the nursing profession.

An inverse relationship between job satisfaction and burnout has been pointed out [1214]. High job satisfaction would be associated with low self-esteem and accelerate burnout in nurses. Sources of dissatisfaction would fulfill the working circumstance of nurses with low self-esteem. That was one reason why $\mathrm{RN}$ in hospitals presented lower self-esteem than UEN.

Discretion and responsibility as a nurse are related to professional fulfillment. The odds ratio for a reduction in self-esteem in the dissatisfaction group was 2.5 times. Husted [15] reported that a lowering of the self-esteem of nurses is closely related to the incidence of burnout, which leads to early resignation. Low fulfillment on the part of an individual with his or her role may cause them to resign. Past studies have reported that stress due to role conflict experienced by nurses reduced their level of occupational satisfaction [16-19]. Bakker [20] observed an association between effort-reward imbalance and burnout among nurses.

The risk (odds ratio) for a reduction in self-esteem for LPN was 4.07 times higher than for $\mathrm{UEN}$, and 2.2 times higher than for RN. Although no differences were observed between the nursing divisions of RN and LPN, significant differences were apparent in the performance by LPN of certain job tasks, because LPN are treated as unskilled workers. These factors were analyzed using discriminant analysis, and referred to as follows, 1 : Advanced assessment skills, 2 : Advanced technical skills, 3 : Advanced communication skills, and 4 : Nursing plan and documentation. As skills $1-3$ are difficult to obtain through college education even for an $\mathrm{RN}$, they have to be acquired through on the job training after graduating, while 4 is a basic technique that clearly determines the level of nursing ability. These skills 
are advanced techniques that may be related to the level of professional satisfaction. Many LPN expressed dissatisfaction with the opportunities available to them. Trucco [21] also reported that job stress and dissatisfaction were closely associated with the occupational level (professionalism). Continuous education and a feedback system for various levels of nurses are needed.

As a limit of this research, UEN were blaced under job hunting, so high self-esteem nurses might have been included, compared with nurses who had abandoned the hope of work. If this fact is excluded, it can be suggested that dissatisfaction regarding professional performance had a relationship with low self-esteem.

\section{Conclusion}

Employed nurses had lower self-esteem than unemployed nurses did. Factors significantly affecting low self-esteem that were not correlated with one another were working status and qualifications ( RN, LPN), limited experience as a nurse and dissatisfaction with discretion and responsibility in work. Job dissatisfaction is closely associated with the level of professional training.

\section{References}

1. Nursing Section, Health Policy Bureau, Ministry of Health and Welfare (1998): Statistical data in nursing. Japanese Nursing Association Press (JNAP), Tokyo (in Japanese)

2. Japanese Nursing Association (JNA) (1994) : The survey and analysis of the resignation of hospital nurses and the ways to encourage nurses to stay in the profession. JNAP, Tokyo pp 7-69 (in Japanese)

3. Rosenberg M (1965) : Society and adolescent self-image. Princeton University Press, Princeton $356 \mathrm{pp}$

4. Endou T, Inoue S \& Ran C (1992) : Psychology of self-esteem. Nakanishiya Press, Kyoto pp $48-53$ (in Japanese)

5 . Inaoka H, Matsuno K \& Miyazato K (1984): A study for burnout in nurses and related factor. Nursing 36: 81-104 (in Japanese)

6. Inaoka H (1984) : Analysis on tendency of nurses fallen burnout. J Nursing 48 : 993-997 (in Japanese)

7 . Strickland O \& Waltz C (ed) (1988): Measurement of Nursing Outcomes. Springer Publishing, New York pp 109-121

8. Munekata T \& Oikawa N (1986) : Reality shock. Kango Tenbou $11: 562-567$ (in Japanese)

9 . Kandlin I (1993) : Burnout of female and male nurses in shiftwork. Ergonomics 36 : 141147

10. O’Brien S \& Srewart P (1994): Self-efficacy, perfectionism, and stress in Canadian nurses. 
Can J Nurs Res 26: 49-61

11. Fimian M, Fastenau P \& Thomas J (1988) : Stress in nursing and intentions of leaving the profession. Psychological Reports 62: 499-506

12. Al-Ma' aitah R, Cameron S, Horsburgh ME \& Armstrong-Stassen M (1999) : Predictors of job satisfaction, turnover, and burnout in female and male Jordanian nurses. Can J Nurs Res 31 : 1530

13. Cameron SJ, Horsburgh ME \& Armstrong-Stassen M (1994) : Job satisfaction, propensity to leave and burnout in RNs and RNAs: a multivariate perspective. Can J Nurs Adm 7: 43-64

14. Dolan N (1987) : The relationship between burnout and job satisfaction in nurses. J Adv Nurs $12: 3-12$

15. Husted GL, Miller MC \& Wilczynski EM (1989) : Retention is the goal: Extinguish burnout with self-esteem enhancement. J Continuing Education in Nursing 20: 244-248

16. Duquette A, Kerouac S \& Sandhu BK (1994): Factors related to nursing burnout: A review of empirical knowledge. Issues in Mental Health Nursing 15: 337-358

17. Minaki H (1988) : Inference of burnout in respect of psychiatric nursing. Nursing Study 21 : $132-139$ (in Japanese)

18. Pranulis MF, Renwanz-Boyle A, Konras AS \& Hodson WL (1995) : Identifying nurses vulnerable to role conflict. International Nursing Review $42: 45-50$

19. Healy CM \& McKay MF (2000) : Nursing stress: the effects of coping strategies and job satisfaction in a sample of Australian nurses. J Adv Nurs 31: 681-688

20. Bakker AB, Killmer CH, Siegrist J \& Schaufeli WB (2000) : Effort-reward imbalance and burnout among nurses. J Adv Nurs 31: 884-891

21. Trucco M, Valenzuela P \& Trucco D (1999) : Occupational stress in health care personnel. Rev Med Chil 127: 1453-1461 
正看護婦と准看護婦の自尊感情の低下に影響する職業要因:多変量解析による分析

\section{今井 香織}

産業医科大学産業保健学部 第三看護学教室

要＼cjkstart旨：＼cjkstart職場のストレスと不満は自尊感情の低下につながり早期離職を促す要因となるため, 看護婦の自尊感情を低下させる職業要因を検討した。解析対象者は病院勤務の正看 護婦552名と准看護婦146名, 離職後求職中の正看護婦（求職看護婦）352名である. 質問項目は個人属性，Rosenbergの自尊感情，仕事に関する満足度,看護業務に関す る64項目別経験頻度とした。その結果最も影響が大きい項目は就業と資格であり， 求職看護婦に比べて就業正看護婦は低自尊の危険が高く, さらに准看護婦は高く調 整オッズレイシォー4.07を示した。次いで経験年数の短さ，仕事の自律性と責任に 関する不満が，独立の危険要因として示された。次に正看護婦と准看護婦の業務内 容の違いを表す判別基準を, 判別分析により求めた。アセスメント，応用的看護技 術，コミュニケーション，看護計画と記録の 4 項目が得られ, 正判別率は70.8\%を 示した。継続的な卒後教育の重要性が指摘される。

J UOEH（産業医大誌） 23 (1) : 13-22（2001） 